) Innlegg på inntil $\mathbf{4 0 0}$ ord lastes opp i http://mc.manuscriptcentral.com/tidsskriftet.

Redaksjonen forbeholder seg retten til å foreta redaksjonelle endringer.

Forfattere av vitenskapelige artikler har tilsvarsrett (jf. Vancouver-gruppens regler).

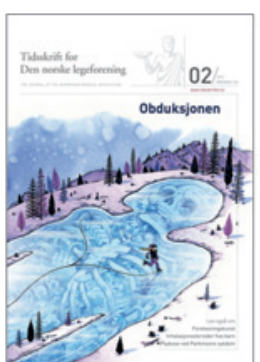

\section{Om rituell omskjæring og helsehjelp}

Professor i medisinsk etikk, teologen Jan Helge Solbakk og hans medforfattere, får en profilert plass til en kommentar om rituell omskjæring og helsehjelp i Tidsskriftet 2/2012 (1). Det er noe uklart om kommentaren står for seg selv eller samtidig er et høringssvar til Helse- og omsorgsdepartementet. Uansett er jeg noe forbauset over at en høring fra myndighetene, der det bes om svar på om hvorvidt omskjæring av guttebarn bør inngå i et organisert og kostnadsdekket helsetilbud, med en gang gjenopptar diskusjonen om et forbud.

Den medisinske argumentasjonen vil kunne besvares senere. Med hensyn til den økonomiske argumentasjonen kan jeg langt på vei være enig med forfatterne, $\mathrm{i}$ og med at en komité som jeg ledet på vegne av myndighetene om det samme emnet, allerede i 1999 tilrådet at dette inngrepet burde gjøres innenfor spesialisthelsetjenesten mot en forhøyet egenandel, som det er lovmessig mulighet til å regulere. Det er bare å beklage at dette ikke ble implementert allerede den gangen.

Jeg setter derimot et spørsmålstegn ved selve det etiske elementet i professorens stadige «korstog» mot dette inngrepet. I innlegget sier forfatterne at de synes det er: «påfallende at departementet gjengir dette synet uten å belegge påstanden og uten å informere om at «mange» av dem som har uttalt seg om de medisinske fordelene ved omskjæring av guttebarn, har en kulturell og religiøs interesse av å legitimere denne praksisen (1).»

Kort sagt synes jeg Solbakk har en slem tendens til å benytte seg av gamle stereotypier i sin kamp mot rituell omskjæring. I «forrige runde » i dette ofte gjentatte temaet, sommeren 2010, uttalte han følgende: «Hadde ikke omskjæring vært praktisert av jøder, så hadde det vært forbudt. Man trår mer forsiktig overfor jøder enn muslimer (2).» Dette utsagnet er nesten egnet til å inngå i konspirasjonstankene vi stadig møter omkring «det jødiske verdensherredømmet», og stemmer dessverre ikke med jødiske erfaringer i Norge.

Undertegnede, som vel representerer «mange av dem» som tidsskriftsinnlegget sikter til, er noe forbauset over at det tilsynelatende skulle være forbudt å ha meninger og ytringer om medisinske fakta med annen kulturell og religiøs bakgrunn enn den lutherske. Vi ville aldri nekte Solbakk å ha sine meninger, selv med hans bakgrunn som teolog i henhold til Den norske statskirken. Jeg har aldri lagt skjul på min bakgrunn. Mener forfatterne at det $i$ enkelte saker skal herske et meningsforbud, eller at man skal behøve å erklære sin religiøse og annen tilhørighet før man får gi uttrykk for sine meninger?

I mellomtiden uttrykker jeg håp om at myndighetene vil ta sin beslutning i saken på basis av svarene på det de egentlig spør om når de inviterer til høring, og ikke de eventuelt vikarierende motivene som måtte dukke opp.

\section{Rolf Kirschner}

Gynekologisk avdeling

Kvinne- og barneklinikken

Oslo universitetssykehus

Rolf Kirschner (f. 1946) er seksjonsleder LIS/ overlege vedGynekologisk avdeling, Oslo universitetssykehus. Han er leder av FaMe-gruppen. Ingen oppgitte interessekonflikter.

\section{Litteratur}

1. Solbakk JH, Pedersen R, Alnæs AH. Rituell omskjæring er ikke helsehjelp. Tidsskr Nor Legeforen 2012; 132: 134-5.

2. Lavalette T. - Jødene hindrer omskjæringsforbud. ABC Nyheter 6.6.2010. www.abcnyheter.no/ nyheter/100806/jodene-hindreromskjaeringsforbud (3.2.2012).

\section{Rituell omskjæring er helsehjelp}

I Tidsskriftet nr. 2/2012 argumenterer Jan Helge Solbakk og medarbeidere mot at omskjæring kan være sykdomsforebyggende (1). De viser til studier om forekomst av hiv i Afrika som har påvist at den lavere forekomsten av hiv i deler av Afrika der man praktiserer omskjæring, snarere skyldes strengere seksualmoral og sosial kontroll av seksualiteten hos muslimske menn og kvinner (1).

Imidlertid finnes det dokumentasjon på at rituell omskjæring er forebyggende.
Blant annet påviser flere studier sammenheng mellom humant papillomvirus (HPV) og omskjæring av menn. I Sør-Afrika har det vært vist at omskjæring kan bremse spredningen av både hiv og HPV (2). I en studie fra Uganda viste forskerne at omskjæring av menn reduserer risikoen for at smitte med HPV-virus med omtrent en tredel, og at risikoen for å få genital herpes reduseres med over en firedel (3). En annen studie, utført i Uganda, viste at risikoen for å pådra seg herpes- virus 2 ble redusert med $28 \%$ og risikoen for å få HPV-viruset ble redusert med $35 \%$ etter omskjæring (4). Studien er uten tvil utført på ikke-muslimer, da deltakerne i studiet ble omskåret i voksen alder. Muslimer og jøder blir vanligvis omskåret i tidlig barnealder.

Solbakk og medarbeidere hevder at (mutilerende) omskjæring er i strid med FN, EU, menneske- og barnerettigheter. Et internasjonalt forskerteam konkluderte imidlertid i 2007 etter studier særlig i Kenya og Uganda med at omskårne menn som har sex med en hivsmittet kvinne, i mindre grad blir smittet. FNs barnefond UNICEF tok konsekvensen av denne kunnskapen og anbefalte at gutter og menn i det sørlige og østlige Afrika skulle bli omskåret. I USA vurderte Centers for Disease Control and Prevention (CDC) i 2009 om man skulle anbefale omskjæring av alle guttebarn for å forebygge hivsmitte (4).

Solbakk og medarbeidere argumenterer for at omskjæring av guttebarn bør forbys på linje med kvinnelig omskjæring. Men kvinnelig omskjæring kan ikke sammenliknes med omskjæring av guttebarn. Omskjæring av kvinner er forbudt i de fleste muslimske land. Det er en gammel egyptisk tradisjon, som praktiseres av så vel kristne som muslimer i nordøstlige deler av Afrika.

Flere studier tyder altså på at omskjæring har en forebyggende effekt, særlig med henblikk på HPV. Forslaget fra Helse- og omsorgsdepartementet omhandler kun en del av befolkningen i Norge (muslimer og jøder), som etter min mening bør få helsehjelp for å sikre at omskjæring av guttebarn skjer under forsvarlige forhold i det norske helsevesen.

\section{Ayad Heidari \\ Nytorget Legesenter \\ Mo i Rana}

Ayad Heidari (f. 1961) er kommunelege i Mo

i Rana.

Ingen oppgitte interessekonflikter. 